\title{
Ethnobotanical Research at the Kutukú Scientific Station, Morona-Santiago, Ecuador
}

\author{
Jose Luis Ballesteros, ${ }^{1,2}$ Francesco Bracco, ${ }^{3}$ Marco Cerna, ${ }^{1}$ \\ Paola Vita Finzi, ${ }^{2}$ and Giovanni Vidari ${ }^{2}$ \\ ${ }^{1}$ Department of Life Sciences, Universidad Politécnica Salesiana, Av. Isabel La Católica 23-52, Quito, Ecuador \\ ${ }^{2}$ Department of Organic Chemistry, University of Pavia, Viale Taramelli 10, 27100 Pavia, Italy \\ ${ }^{3}$ Department of Territorial Ecology and Environment, University of Pavia, Via S. Epifanio 14, 27100 Pavia, Italy \\ Correspondence should be addressed to Jose Luis Ballesteros; jballesterosl@ups.edu.ec
}

Received 7 June 2016; Accepted 21 November 2016

Academic Editor: Ronald L. Klein

Copyright (C) 2016 Jose Luis Ballesteros et al. This is an open access article distributed under the Creative Commons Attribution License, which permits unrestricted use, distribution, and reproduction in any medium, provided the original work is properly cited.

This work features the results of an ethnobotanical study on the uses of medicinal plants by the inhabitants of the region near to the Kutukú Scientific Station of Universidad Politécnica Salesiana, located in the Morona-Santiago province, southeast of Ecuador. In the surroundings of the station, one ethnic group, the Shuar, has been identified. The survey hereafter reports a total of 131 plant species, with 73 different therapeutic uses.

\section{Introduction}

Plants have played a fundamental role for the development of Andean cultures ever since man first arrived to that region approximately 10000 years ago [1]. Through history, man has utilized vegetable resources as a source of nutrition, medicines, fuel, and building materials and they even occupied an important place within their belief system and rites [2].

According to the World Health Organization $[3,4]$ about $80 \%$ of the world population uses natural remedies and traditional medicine. Such medicine comes from forest resources that provide a series of benefits to the local, regional, and national populations and include raw materials, patrimony protection, and scenic beauty [5]. Nowadays, Ecuador, located on the equator line, is considered as one of the countries with the greatest biodiversity in the world [6]. In Ecuador, there exist many areas of biological interest that for their unique features currently provide diverse uses for the benefit of the population [7]. These uses of natural resources are the fruits of the accumulation of the ancestral knowledge that the local population has kept until now [8]. This traditional knowledge has been orally transmitted from one generation to the next, but over the last decades, the crisis of the rural world threatens this rich patrimony, which may be lost, together with many interesting aspects concerning the traditional exploitation of natural resources [9].

In Ecuador, many ethnobotanical studies have been made: that is, Villacrés [10] studied the bioactivity of plants of the Amazon jungle from the province of Napo; Cerón and Montalvo [11] published a book on the ethnobotanical aspects of the "Huaorani" people in a specific zone in the northeast of Ecuador; the cultural practices of Quechua society in Napo were analyzed in a book by Iglesias [12]; Tene et al. [13] performed an ethnobotanical study on medicinal plants used in Loja and Zamora Chinchipe. A few studies have also been made concerning the traditional use of plants in the Saraguro community of south Ecuador [14-16].

In this work we analyzed the ethnobotanical patrimony of Kutukú Scientific Station, located on the Kutukú mountain range in the Morona-Santiago province, Ecuador. By doing that, we intended to safeguard the popular knowledge concerning plants and to produce a database of plant uses and advantages. This data could be used by the citizens themselves and could be the base for future actions in programs of scientific investigations, environmental education, social 


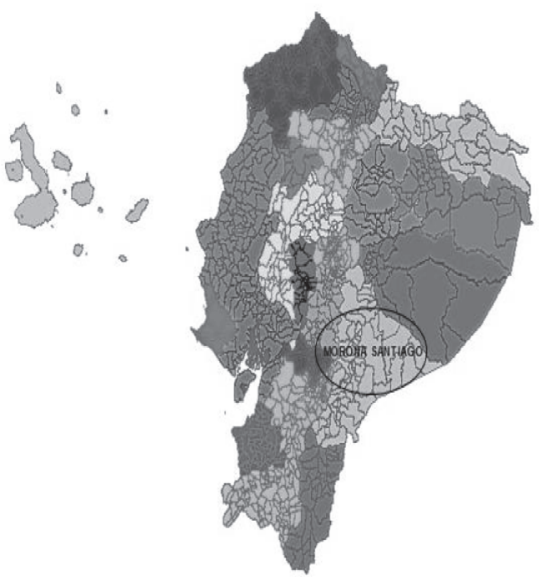

(a)

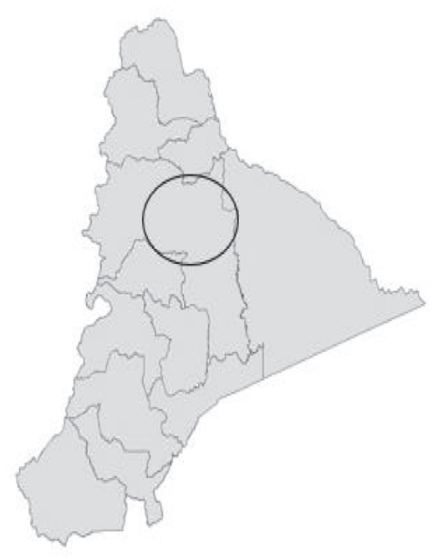

(b)

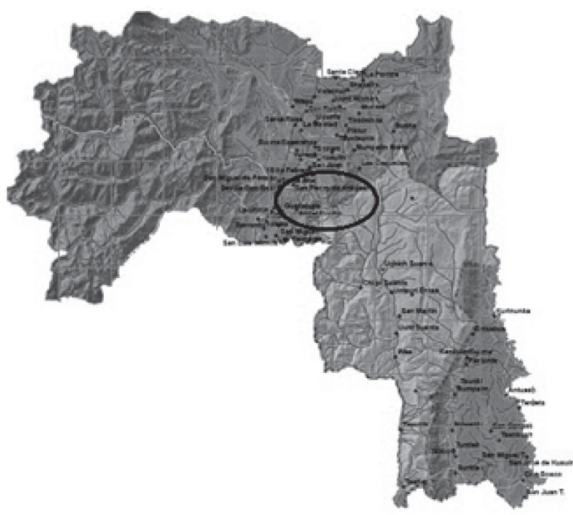

(c)

FIGURE 1: Region where the study was carried out. (a) Location in Ecuador, (b) location in the province, (c) location in the canton. Source: Geographical Information Systems (IGM and SENPLADES).

TABle 1: Communities close to the area of the Kutukú Scientific Station and its buffering zone.

\begin{tabular}{lcc}
\hline Canton & Parrish & Community \\
\hline & & Sevilla Don Bosco \\
& San Luis Inimks \\
& & Santa Ana \\
Morona & Sevilla & San Miguel \\
& & Guadalupe \\
& Angel Rouby \\
& Ankuash \\
\hline
\end{tabular}

awareness, and natural resources exploitation, as well as the start point of touristic attraction based on the sustainable development of the territory.

\section{Methodology}

The research herein was performed between August and December of 2013, within the area of the Kutukú Biological Station belonging to Universidad Politécnica Salesiana del Ecuador $\left(2^{\circ} 18^{\prime} 39.1^{\prime \prime} \mathrm{S}, 78^{\circ} 06^{\prime} 11.6^{\prime \prime} \mathrm{W}\right)$ with $800-1200 \mathrm{~m}$ a.s.l. The territory of the station covers 250 hectares and is located within the Kutukú-Shaimi Protected Forest (BPKS) in the center of Ecuador's eastern region, east of the city of Macas, in the parish of Sevilla Don Bosco, province of Morona-Santiago (Figure 1).

Within the area of the scientific station, big forest extensions of the evergreen humid type, really difficult to access, still persist in the low montane, montane, and high montane belts [17]. The month average temperature ranges between 16 and $27^{\circ} \mathrm{C}$, and the total annual precipitation is $3021 \mathrm{~mm}$ approximately [18]. Close to the territory of the scientific station, where this study was carried out, about 7 indigenous communities can be found; all of these belong to the ethnic group "Shuar" (Table 1).
For this investigation, a qualitative ethnobotanical method was carried out [20] in which mostly adult persons have been contacted, who live within the area under study and know the use of medicinal plants. One hundred and sixty inhabitants of the seven communities were interviewed. All respondents were farmers or elderly belonging to the "Shuar" ethnicity or their descendants.

The collected data were processed and the results are expressed in a list of medicinal plants, with scientific names, families, collection point, used parts, form of preparation, traditional uses, and distribution (Table 2). The plant samples were processed and identified at the Ecuadorian National Herbarium (QCNE). They were deposited with their respective code at the Herbarium of the Universidad Politécnica Salesiana in the city of Quito, Ecuador. The botanic nomenclature was registered according to the Catalog of Vascular Plants of Ecuador [6]. A contact was established with the Shuar community through their authorized representatives, with the possibility of performing more precise studies in the future for the recovery, protection, and sustainable use of their traditional knowledge.

\section{Result and Discussion}

The ethnobotanical study performed in this work gave us a real panorama about the natural remedies used by the inhabitants in the territory of the Kutukú Scientific Station of the Morona canton of the province of Morona-Santiago, south of Ecuador. This research was realized with "Shuar" community, which is very different from the "Achuar" community cited in the article by Giovannini [21], even the geographical location and the altitude are different.

One hundred thirty-one different plants have been identified, which many medicinal properties have been attributed to; their uses and forms of therapeutic usage also have been recorded. From the total number of plants, 107 are native, 9 are grown traditionally, 9 are endemic, and 6 are cultivated [6]. 


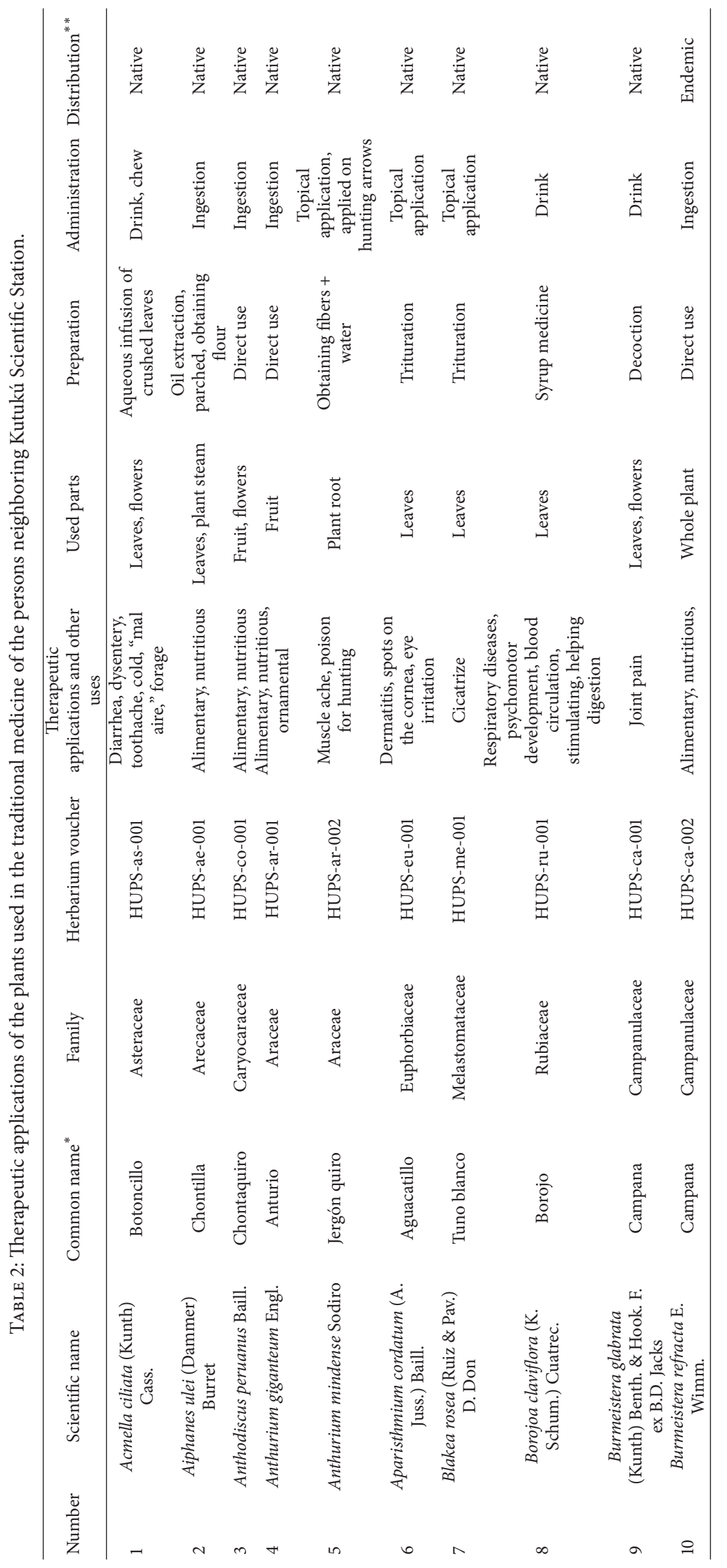




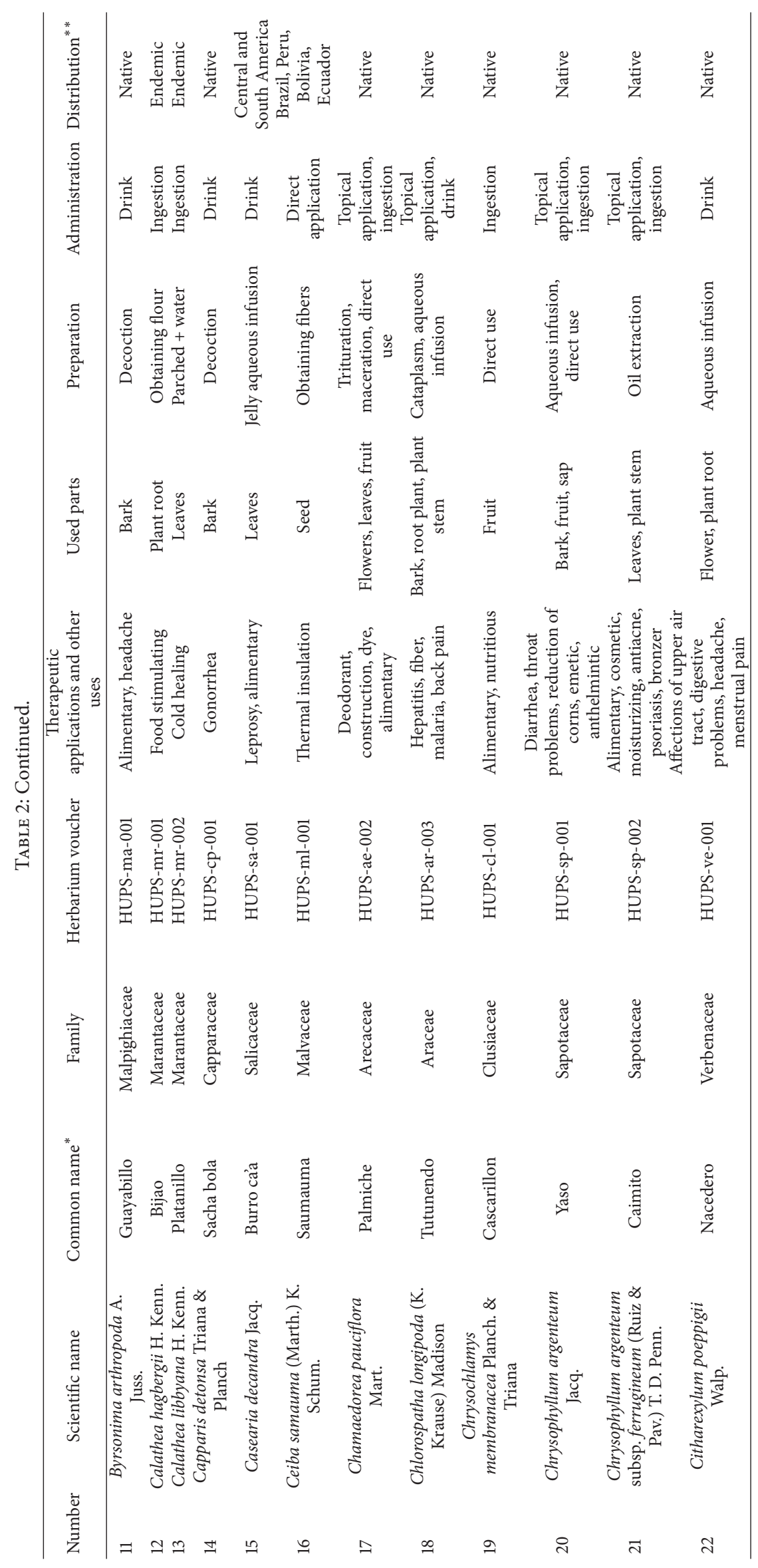




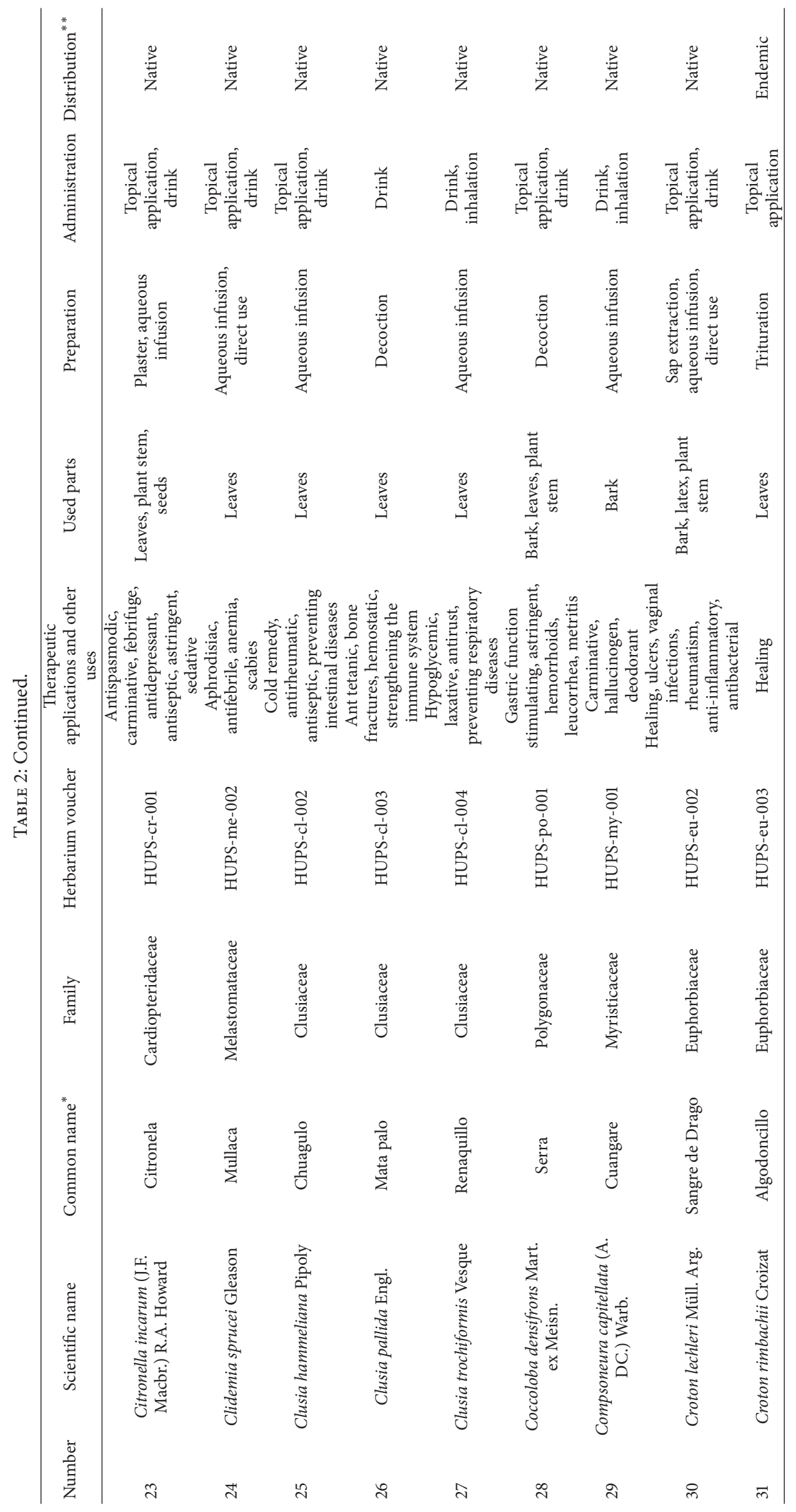




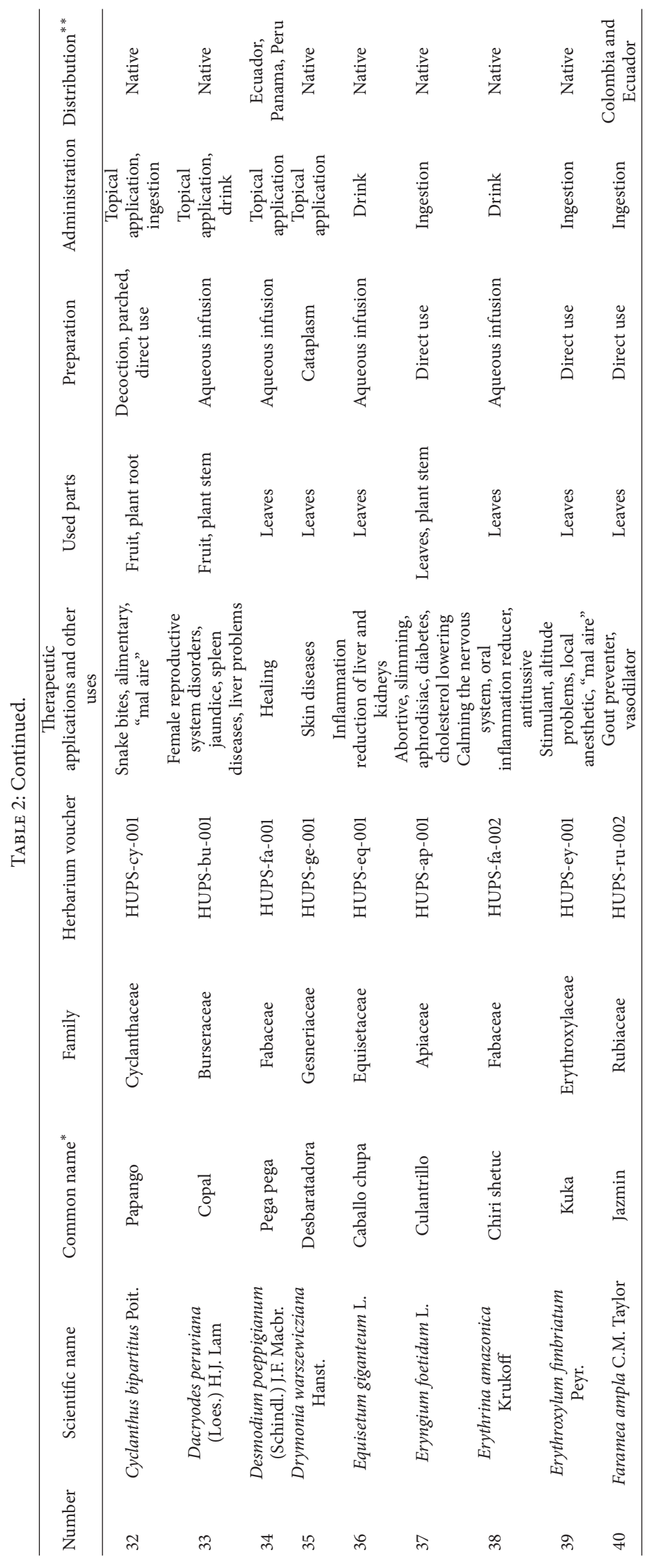




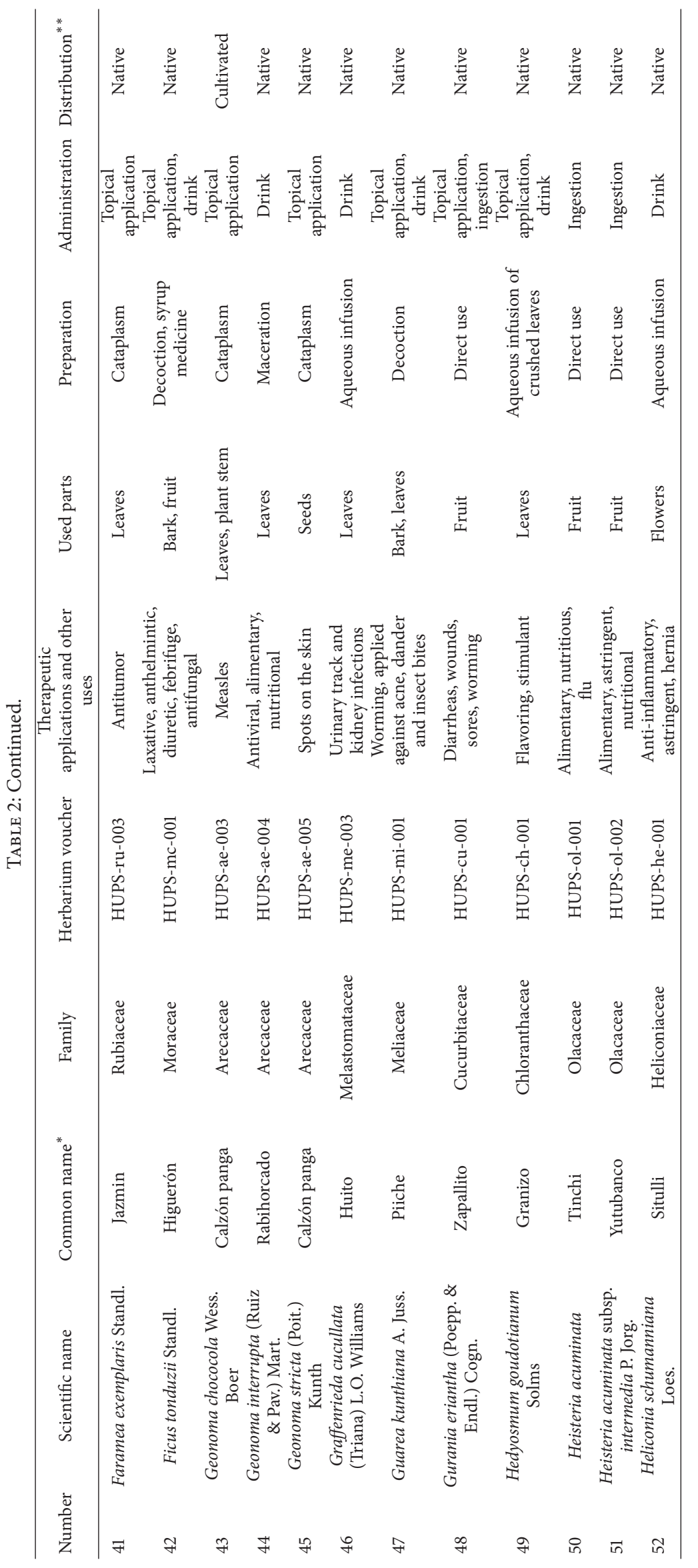




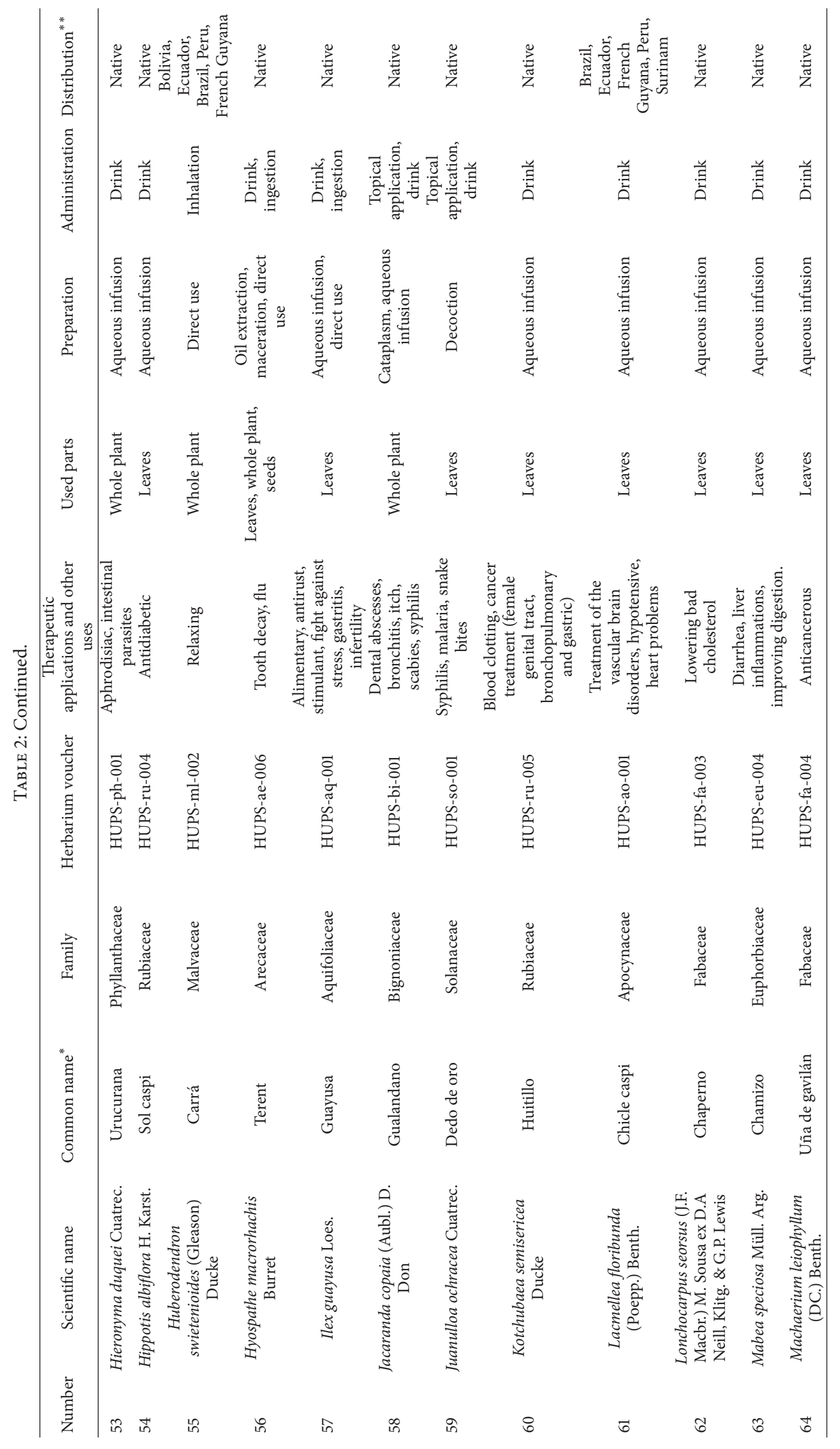




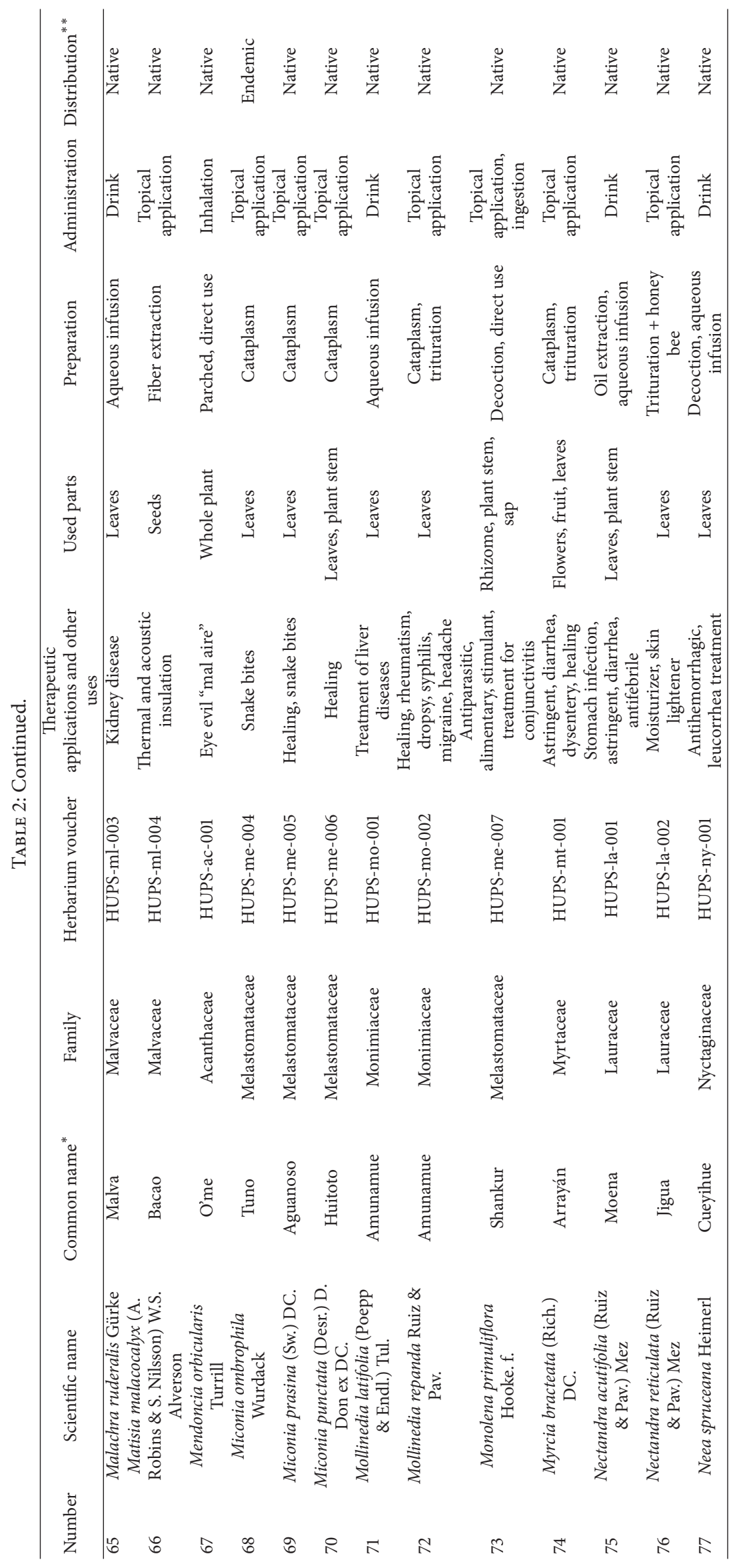




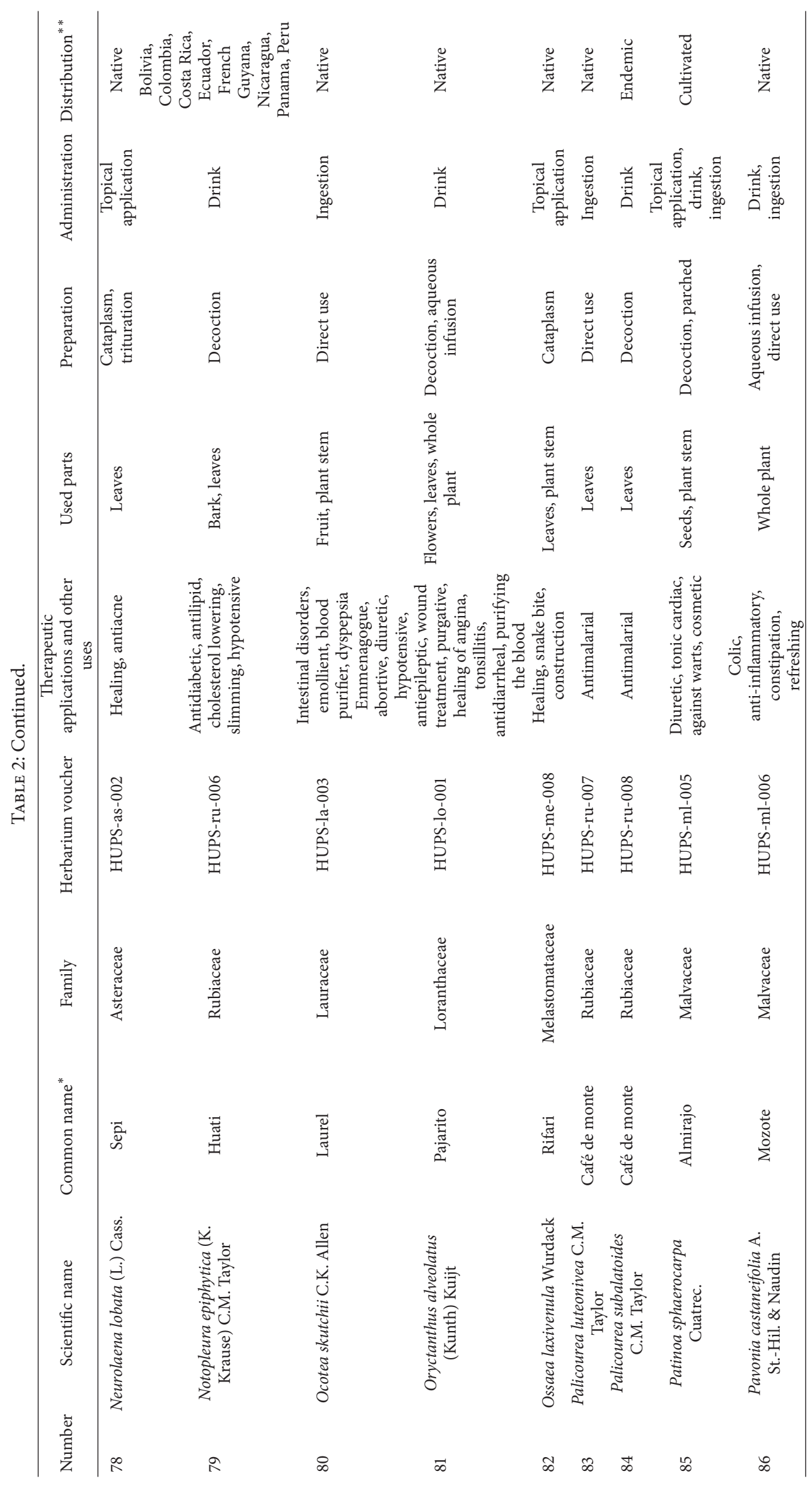




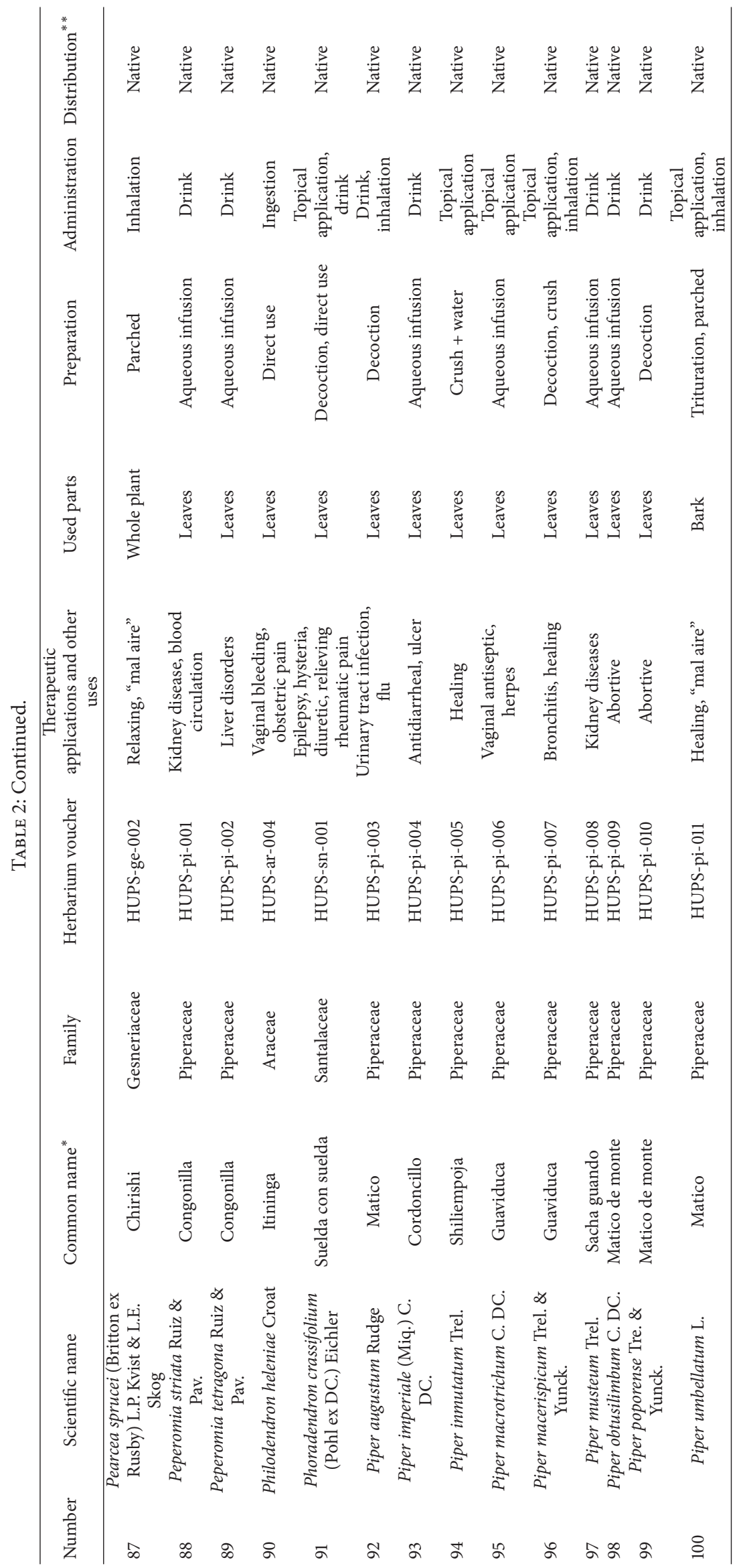




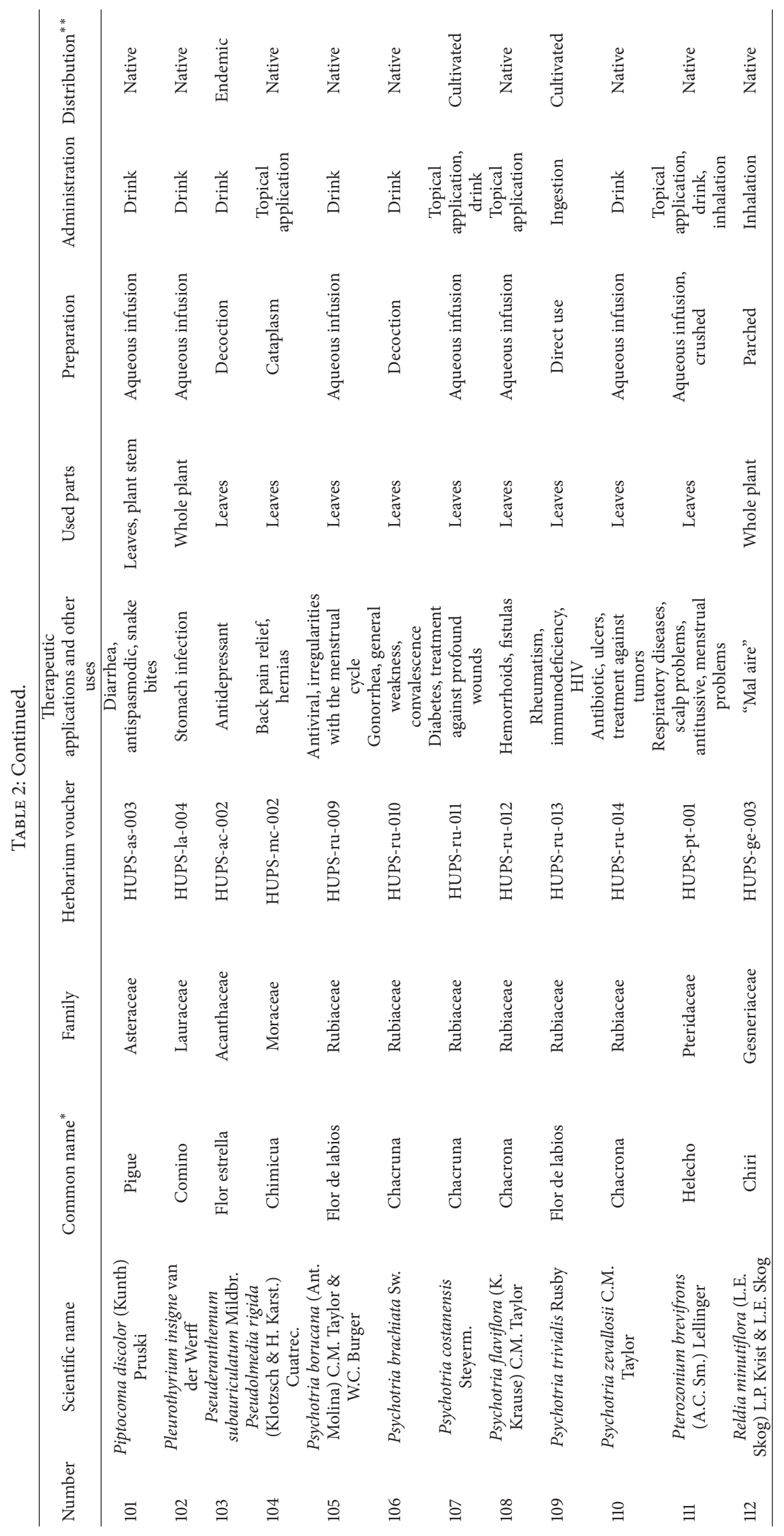




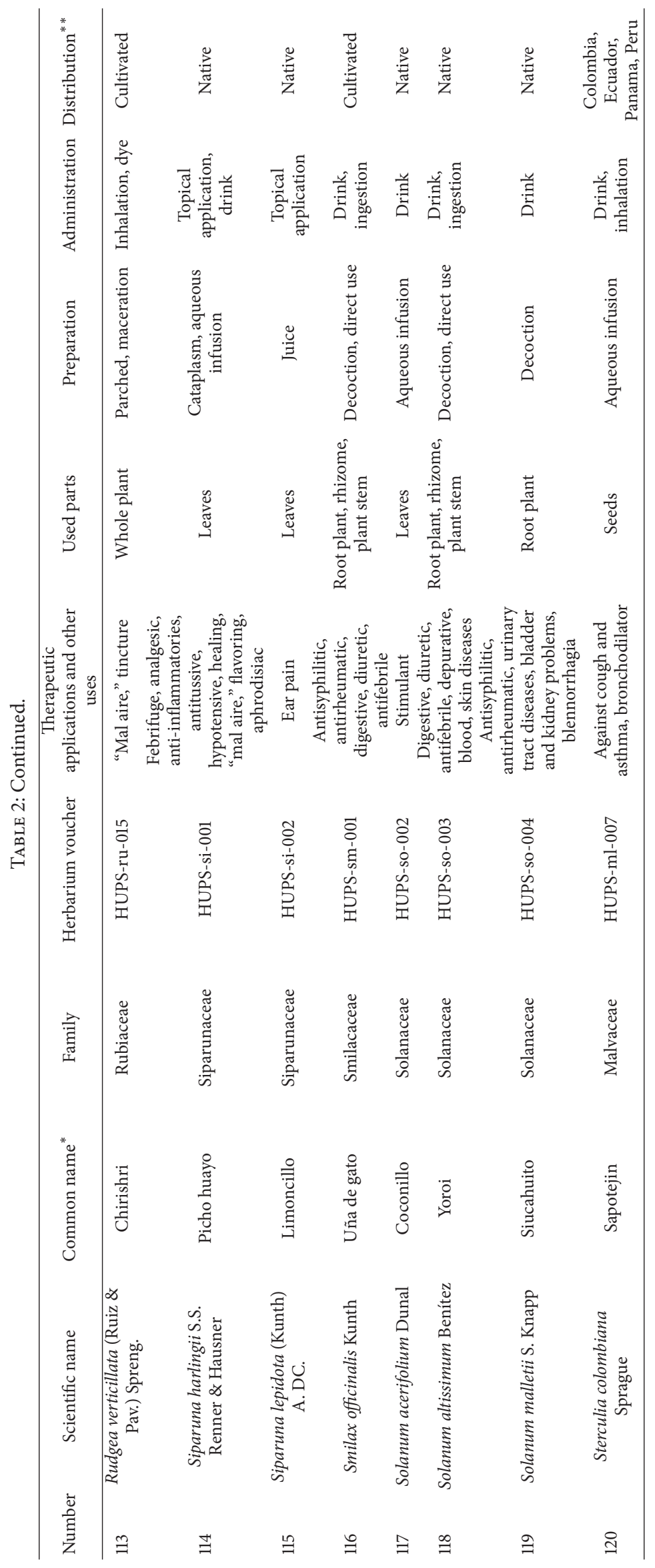




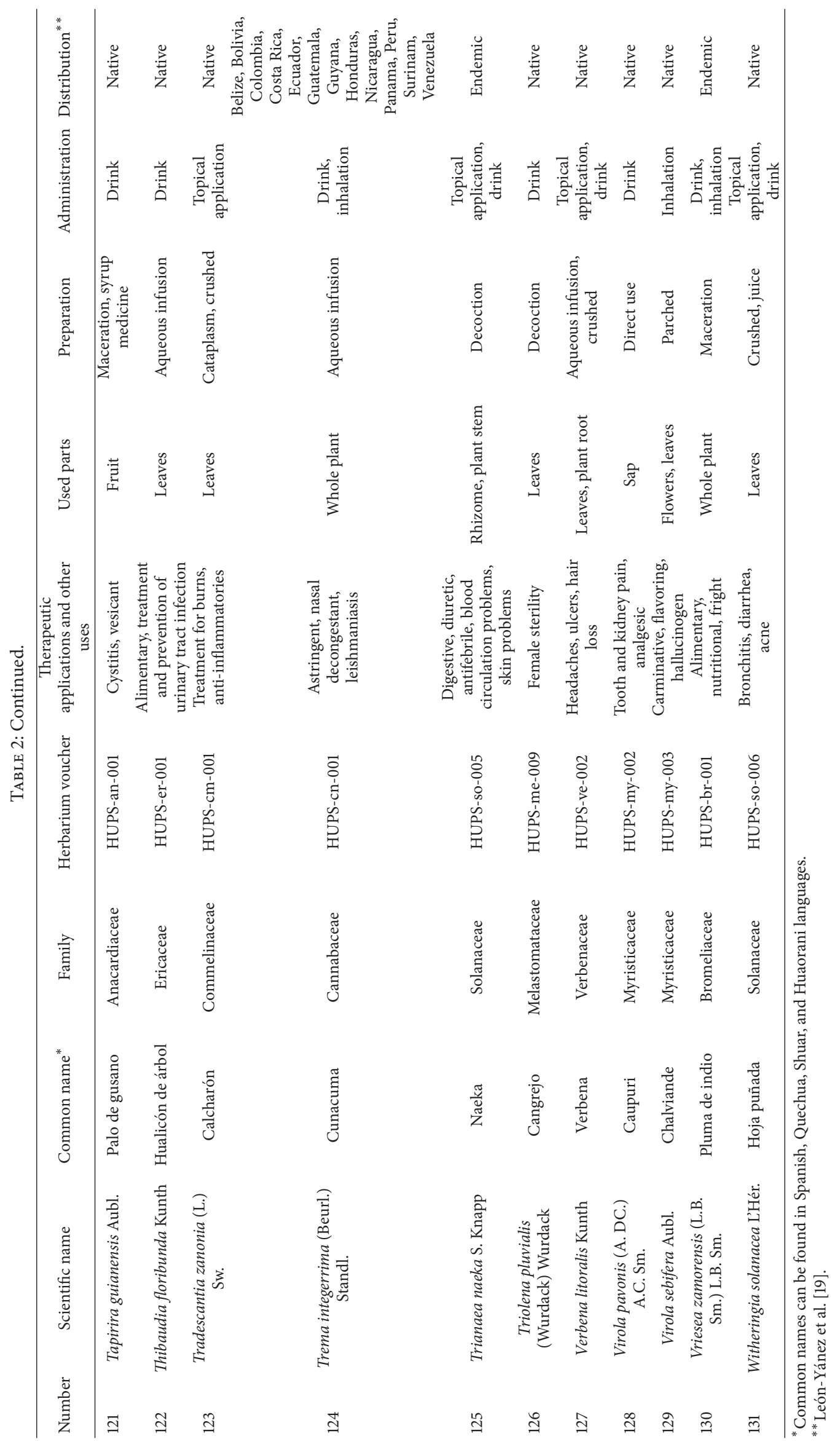




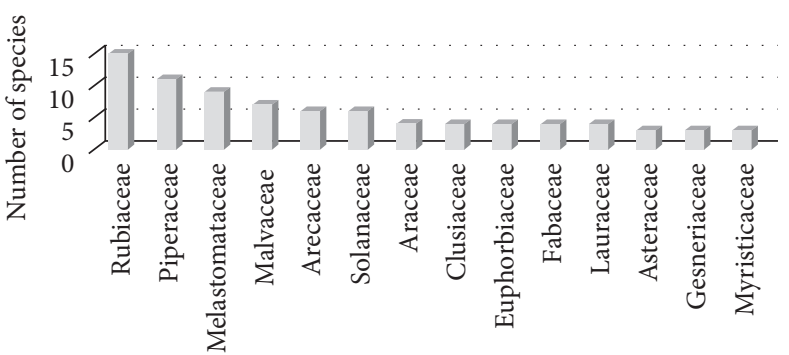

Families

Figure 2: The most frequently used families of plants in the area of Kutukú Scientific Station.

This long list of plants comprises species yet unknown from a phytochemical point of view, as well as deeply studied ones, for example, Croton lechleri Müll. Arg. and Ilex guayusa Loes. Croton lechleri is used locally as a wound healing aid, as a treatment for ulcers and sometimes for vaginal infections. These usages and other are scientifically validated in literature, especially concerning the treatment of infections and the wound healing aid [22]. According to another author [13], Croton lechleri is traditionally used in Ecuador as a diuretic remedy and is also employed to treat dermatologic and hepatic illnesses.

Ilex guayusa is used in case of gastritis, as a stimulant replacing coffee, and to enhance fertility in women. In the Amazon forest of Ecuador and Peru, a traditional guayusa decoction that yields a high content of caffeine is used as a stimulant in the morning [23]. It is also reported [24] that Ilex guayusa of Peru has a strong antimicrobial activity.

Verbena litoralis Kunth keeps being very appreciated in local medicine, particularly for the treatment of headaches, ulcers, and alopecia. Data in scientific literature [25] support its activity as an analgesic too.

According to the collected information, the plants utilized for headache treatment are Virola pavonis (A. DC.) A. C. Sm., Siparuna harlingii S. S. Renner \& Hausner, Byrsonima arthropoda A. Juss., Acmella ciliata (Kunth) Cass., and Citharexylum poeppigii Walp.

Virola pavonis is used and very appreciated by the local inhabitants for the treatment of diseases, from inflammation to headache, from hangovers to renal problems. Outside Ecuador, this plant was tested in Brazil for the treatment of leishmaniosis [26], while the antifungal activity of the extracts from the leaves was studied in detail by Zacchino et al. [27]. The leaves of Siparuna harlingii S. S. Renner \& Hausner are used by the local inhabitants as remedies for headache and cough and as an anti-inflammatory. At other latitudes, different authors described diverse applications of this plant: in Zamora Chinchipe province of Ecuador, the inhabitants employ it against rheumatism [28]; meanwhile in Colombia, it is used to treat illnesses of nervous system and stomach [29].

The bark of Byrsonima arthropoda in decoction is employed as an analgesic, although the whole plant is used as food for birds and mammals. The Makuna Indians from Praparaná River, a Colombian Amazon ethnic group, uses the ground plant as a wound healing aid [30].
In our study we found that the leaves of Acmella ciliata are used as a remedy against diarrhea, headaches, colds, and toothache and for "mal aire." Only a few papers are available in literature, either ethnopharmacologic or phytochemical, for Acmella ciliata. In a study performed in the state of Minas Gerais in Brazil [31] it is reported that the leaves of this plant are traditionally used to treat hepatic problems.

From the flowers and leaves of Citharexylum poeppigii aqueous infusions are prepared, which are used to treat affections of upper respiratory tract such as cough. This infusion is also used for digestive discomfort, headaches, and menstrual cramps. In literature information concerning the ethnobotanical use of this species is lacking; nonetheless, the presence of this plant is confirmed in Ecuador [32] and Venezuela [33].

The plant families mostly used by the inhabitants are $\mathrm{Ru}-$ biaceae (15), Piperaceae (11), Melastomataceae (9), Malvaceae (7), Arecaceae (7), Solanaceae (6), and Euphorbiaceae (4). Figure 2 shows the plant families reported in this study with a main role in the traditional use.

In the area of Kutukú Scientific Station plants of the Rubiaceae family are used mostly as anticarcinogens (4), for circulatory system problems (4), as a treatment for diabetes (3), and against malaria (2). In literature plants of the Rubiaceae family are reported as being antihepatotoxic [34], as well as having anti-inflammatory and analgesic activities [35].

Piperaceae plants are often used locally against kidney and urinary tract affections (3), as wound healing aids (3), and curiously sometimes as an abortive (2). The use of the plants of this family in infusions of whole plant is frequently reported in the literature, which confirms the usage as wound healing aid [36] and for the treatment of kidney affections [37].

In this study we found that the plants of the Melastomataceae family are used especially as treatment of poisonous snake bites and for wound healing (4). Many plants of this family are used in Mexico for the traditional treatment of gingivitis and oral infections overall [38] and have been tested in Brazil for treating gastrointestinal problems [39].

We confirm the usage of plants of the Malvaceae family as diuretic remedies, as reported, for example, in AlarcónAlonso et al. [40] for Hibiscus sabdariffa L., and also the use of Patinoa sphaerocarpa Cuatrec in the same way. The antiviral properties of the plants of the Arecaceae family, reported, for example, in Cocos nucifera L. from Brazil [41], are confirmed 


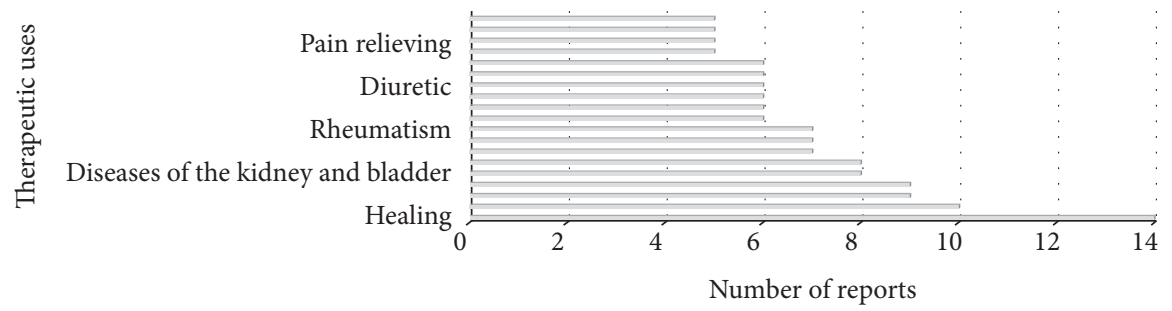

Figure 3: Main therapeutic uses of the plants of the Kutukú Scientific Station reported in this article.

on the base of the species Geonoma chococola Wess. Boer and Geonoma interrupta (Ruiz \& Pav.) Mart found at the Kutukú Scientific Station.

The plants of the Solanaceae family are used generally as a treatment for syphilis (3), rheumatism (2), kidney problems (2), and infections of the urinary tract (2). A study carried out in the Bolivian Chaco pointed out the traditional use of some species of Solanaceae family for the treatment of headaches, fever, acne, and diarrhea [42]; these pharmacological uses can be correlated with our findings. Besides, the Solanaceae family has been broadly studied and its plants are used for their hallucinogenic properties [43].

Plants of the Euphorbiaceae family are used mostly as wound healing aids (2), for intestinal problems (1), for diarrhea (1), and as hepatoprotective agents (1), the latter being confirmed by a study performed in India [44].

Many plants of these families and of the other families reported in this study are used for the treatment of "espanto" or "mal aire," a typical Andean pathology that is poorly defined, in which the psychosomatic problems, originated from phobia factors, produce deep physical and psychological weakness [45]. To talk about etiology of "mal aire" is not just talk about the origin of the disease but rather is to speak of the limits of medicine and get into the field of philosophical approaches; in general the "mal aire" is a state of general decay of the body generated by evil spirits that inhabit the crossing mountains and under large trees, orchards abandoned, ponds, streams, cemeteries, places where they have been burials fact of valuables, and so forth [46].

Overall, 73 different therapeutic uses for the cited plants have been recorded, including their use as wound healing aids (14), for "mal aire" (10), for diarrhea (9), as nourishment (9), for kidney and bladder affections (8), for fever (8), and for rheumatism (7). All of these are indicated in Figure 3.

An aqueous infusion is the most generalized form of administration; decoctions, direct consumption, and topical applications are also common. The leaves (50\%) are the plant parts more frequently selected, followed by the stem (12\%), fruits (16\%), and barks (10\%).

\section{Conclusions}

The use of plants for treating diseases keeps being necessary to indigenous populations in emerging countries which, due to high costs, have a difficult access to western medicines and, therefore, use to rely on their own traditional remedies. On the other hand, the integrated forms of modern and traditional medicines are often practiced by many physicians nowadays. Morona-Santiago, the Ecuadorian province where the Kutukú Scientific Station is located, owns a high plant biodiversity and a rich ethnobotanical tradition based on it. This has given origin to a popular medicine comprising the use of more than 100 local plants, which have been botanically identified. The illnesses cured with the plants are, of course, strictly related with the health situation of local communities. Wound healing aids, renal and stomach infections, headaches, and colds are the most common ailments which natural resources are used for. Nonetheless less frequent diseases, such as cancer, diabetes, and malaria, are also treated with different plant extracts.

On these days, the preservation of traditional knowledge is threatened by a great amount of external factors related to the "modernization" of the region. It is, therefore, urgent to save the cultural patrimony of the indigenous populations, by confirming the therapeutic use of plants with scientific criteria and by encouraging the phytochemical research of the species containing potential active principles of interest.

Within this context, more studies on the use of medicinal plants by the indigenous communities nearby the Kutukú Scientific Station are being carried out by our investigation groups, in which scientists, technicians, and students are involved, assessing the biological activity of the region's most promising plants.

\section{Competing Interests}

The authors declare that there is no conflict of interests.

\section{Acknowledgments}

This study was carried out with the financial support of Universidad Politécnica Salesiana del Ecuador, through the group of investigation on natural resources, with the cooperation and direction of Università Degli Studi di Pavia in Italy. The authors would like to thank Universidad Politécnica Salesiana, Università Degli Studi di Pavia, Colegio Don Bosco in Sevilla parish, Morona-Santiago province, the National Herbarium of Ecuador (QCNE), the UPS Herbarium, the entire personnel of the Center of Research and Valuation of Biodiversity (CIVABI), and all the communities that gave their share of ancestral knowledge during the making of this project. 


\section{References}

[1] E. Almeida, Culturas Prehispánicas del Ecuador, Viajes Chasquiguiñán Cía. Ltda, Quito, Ecuador, 2000.

[2] R. E. Schultes, "The importance of ethnobotany in environmental conservation," Monografías del Jardín Botánico de Córdoba, vol. 5, pp. 157-164, 1997.

[3] R. Chaudhury, Herbal Medicine for Human Health, World Health Organization, Regional Office for South-East Asia, 1992.

[4] WHO, "Summar 9 WHO guidelines for the assessment of herbal medicines," Herbal Grom, vol. 28, pp. 13-14, 1993.

[5] O. Carrero, Estudio Etnobotánico en las Reservas Forestales: Estados Barinas, 1996.

[6] P. Jorgensen and S. León-Yánez, Catalogue of the Vascular Plants of Ecuador, Missouri Botanical Garden Press, St. Louis, Mo, USA, 1999.

[7] Ministerio del Ambiente de Ecuador, Cuarto Informe Nacional para el Convenio sobre la Diversidad Biológica, Ministerio del Ambiente de Ecuador, Quito, Ecuador, 2010.

[8] P. Naranjo and R. Escaleras, La Medicina Tradicional en el Ecuador, Corporación Editora Nacional, Quito, Ecuador, 1995.

[9] L. Villar, "Panorámica de la etnobotánica en España (Pirineos y noroeste peninsular)," Monografías del Jardín Botánico de Córdoba, vol. 5, pp. 165-177, 1997.

[10] V. Villacrés, Bioactividad de Plantas Amazónicas, Abya Yala, Quito, Ecuador, 1995.

[11] C. Cerón and C. Montalvo, Etnobotánica de los Huaorani de Quehueiri-ono Napo-Ecuador, Escuela de Biología y QuímicaUniversidad Central del Ecuador, Quito, Ecuador, 1998.

[12] G. Iglesias, Sacha Jambi. El Uso de las Plantas en la Medicina Tradicional de los Quichuas del Napo, Abya Yala, Quito, Ecuador, 2002.

[13] V. Tene, O. Malagón, P. V. Finzi, G. Vidari, C. Armijos, and T. Zaragoza, "An ethnobotanical survey of medicinal plants used in Loja and Zamora-Chinchipe, Ecuador," Journal of Ethnopharmacology, vol. 111, no. 1, pp. 63-81, 2007.

[14] J. Andrade, C. Armijos, O. Malagon, and H. lucero, Plantas Silvestres Empleadas por la etnia Saraguro en la Parroquia San Lucas, Loja-Ecuador, Ediciones UTPL, Loja, Ecuador, 2009.

[15] C. Armijos, M. Lozano, F. Bracco, G. Vidari, and O. Malagon, Plantas Sagradas y Psicoactivas Usadas por los Saraguros en la Region sur del Ecuador, Ediloja, Loja, Ecuador, 2012.

[16] R. W. Bussmann and D. Sharon, "Traditional medicinal plant use in Loja province, Southern Ecuador," Journal of Ethnobiology and Ethnomedicine, vol. 2, article no. 44, 2006.

[17] R. Sierra, Ed., Propuesta Preliminar de un Sistema de Clasificación de Vegetación para el Ecuador Continental, Proyecto INEFAN/GEF-BIRF y EcoCiencia, Quito, Ecuador, 1999.

[18] CARE, Ministerio del Ambiente, and Unión Europea y Tinker Foundation, Plan de Manejo Actualizado y Priorizado del Bosque Protector Kutukú Shaimi, 2012-2017, CARE, Ministerio del Ambiente, Unión Europea y Tinker Foundation, Macas, Ecuador, 2012.

[19] S. León-Yánez, R. Valencia, N. Pitman, L. Endara, C. Ulloa, and H. Navarrete, Libro Rojo de las Plantas Endémicas del Ecuador, Publicaciones del Herbario QCA, Pontificia Universidad Católica del Ecuador, Quito, Ecuador, 2nd edition, 2011.

[20] L. P. Kvist, I. Oré, A. González, and C. Llapapasca, "Estudio de plantas medicinales en la amazonia peruana: una evaluación de ocho métodos etnobotánicos," Folia Amazónica, vol. 12, no. 1-2, pp. 53-75, 2001.
[21] P. Giovannini, "Medicinal plants of the Achuar (Jivaro) of Amazonian Ecuador: ethnobotanical survey and comparison with other Amazonian pharmacopoeias," Journal of Ethnopharmacology, vol. 164, pp. 78-88, 2015.

[22] A. J. Vaisberg, M. Milla, M. C. Planas et al., "Taspine is the cicatrizant principle in Sangre de Grado extracted from Croton lechleri," Planta Medica, vol. 55, no. 2, pp. 140-143, 1989.

[23] W. H. Lewis, E. J. Kennelly, G. N. Bass, H. J. Wedner, M. P. ElvinLewis, and D. Fast, "Ritualistic use of the holly Ilex guayusa by Amazonian Jivaro Indians," Journal of Ethnopharmacology, vol. 33, no. 1-2, pp. 25-30, 1991.

[24] Q. Ruiz, R. Julio, and A. Mirtha Roque, "Actividad antimicrobiana de cuatro plantas del nor-oriente peruano," Revista de Ciencia e Investigación, vol. 12, no. 1, pp. 41-47, 2009.

[25] N. I. Hilgert and G. E. Gil, "Medicinal plants of the argentine yungas plants of the las yungas biosphere reserve, northwest of Argentina, used in health care," Biodiversity and Conservation, vol. 15, no. 8, pp. 2565-2594, 2006.

[26] S. K. R. Morais, A. F. Teixeira, Z. E. S. Torres et al., "Biological activities of lignoids from amazon Myristicaceae species: Virola michelii, V. mollissima, V. pavonis and Iryanthera juruensis," Journal of the Brazilian Chemical Society, vol. 20, no. 6, pp. 11101118, 2009.

[27] S. Zacchino, G. Rodríguez, G. Pezzenati, G. Orellana, R. Enriz, and M. G. Sierra, "In vitro evaluation of antifungal properties of 8.O.4' -neolignans," Journal of Natural Products, vol. 60, no. 7, pp. 659-662, 1997.

[28] C. Orellana and J. Zulay, Estudio de plantas útiles empleadas en la comunidad Shuar El Kiim-Yacuambi de la provincia de Zamora Chinchipe, (Trabajo de fin de titulación de Ingeniero en Gestión Ambiental). UTPL, Loja, Ecuador, 2014.

[29] S. S. Renner and G. Hausner, "New species of Siparuna (Monimiaceae) I. Four new species from Ecuador and Colombia," Novon, vol. 5, no. 1, pp. 61-70, 1995.

[30] R. E. Schultes, De PlantisToxicariis e Mundo Novo Tropicalecommentationes XXXI: Further Ethnopharmacological Notes on Malpighiaceousplantas of the Northwestern Amazon, vol. 29, no. 2, Botanical Museum Leaflets, Harvard University, Harvard University, 1983.

[31] B. E. Conde, I. T. Salazar Rogerio, A. M. de Siqueira, M. Q. Ferreira, L. M. Chedier, and D. S. Pimenta, "Ethnopharmacology in the vicinity of the botanical garden of the federal university of Juiz De Fora, Brazil," Ethnobotany Research and Applications, vol. 12, no. 1, pp. 91-112, 2014.

[32] H. Moldenke, "The known geographic distribution of the members of the verbenaceae and avicenniaceae supplement 3 ," Castanea, vol. 10, no. 2, pp. 35-46, 1945.

[33] J. Parra and L. Gamez, "Determinación de especies arbóreas a través de caracteres vegetativos en la Estación Experimental Caparo, Estado Barinas, Venezuela," Revista Forestal Venezolana, vol. 56, no. 2, pp. 135-145, 2012.

[34] M. P. Germanò, R. Sanogo, C. Costa et al., "Hepatoprotective properties in the rat of Mitracarpus scaber (Rubiaceae)," Journal of Pharmacy and Pharmacology, vol. 51, no. 6, pp. 729-734, 1999.

[35] A. B. Dongmo, A. Kamanyi, G. Dzikouk et al., "Anti-inflammatory and analgesic properties of the stem bark extract of Mitragyna ciliata (Rubiaceae) Aubrév. \& Pellegr," Journal of Ethnopharmacology, vol. 84, no. 1, pp. 17-21, 2003.

[36] C. C. Neto, C. W. Owens, R. D. Langfield et al., "Antibacterial activity of some peruvian medicinal plants from the callejon de huaylas," Journal of Ethnopharmacology, vol. 79, no. 1, pp. 133$138,2002$. 
[37] M. Rahmatullah, M. A. Rahman, M. Z. Haque et al., "A survey of medicinal plants used by folk medicinal practitioners of station purbo para village of Jamalpur Sadar Upazila in Jamalpur district, Bangladesh," American-Eurasian Journal of Sustainable Agriculture, vol. 4, no. 2, pp. 122-135, 2010.

[38] M. Leonti, H. Vibrans, O. Sticher, and M. Heinrich, "Ethnopharmacology of the Popoluca, Mexico: an evaluation," Journal of Pharmacy and Pharmacology, vol. 53, no. 12, pp. 1653-1669, 2001.

[39] C. H. Pellizzon, A. L. Rozza, P. C. P. Vasconcelos, M. A. Andreo, and C. A. Hiruma-Lima, "Non-commercial plants of medicinal purposes from the Brazilian biomes for the treatment of gastrointestinal diseases," in Drug Plants III, vol. 29 of Information: Recent Progress in Medicinal Plants, pp. 217-236, Studium Press LLC, Delhi, India, 2010.

[40] J. Alarcón-Alonso, A. Zamilpa, F. A. Aguilar, M. HerreraRuiz, J. Tortoriello, and E. Jimenez-Ferrer, "Pharmacological characterization of the diuretic effect of Hibiscus sabdariffa Linn (Malvaceae) extract," Journal of Ethnopharmacology, vol. 139, no. 3, pp. 751-756, 2012.

[41] E. B. C. Lima, C. N. S. Sousa, L. N. Meneses et al., "Cocos nucifera (L.) (Arecaceae): a phytochemical and pharmacological review," Brazilian Journal of Medical and Biological Research, vol. 48, no. 11, pp. 953-964, 2015.

[42] G. Bourdy, L. R. Chavez De Michel, and A. Roca-Coulthard, "Pharmacopoeia in a shamanistic society: the Izoceño-Guaraní (Bolivian Chaco)," Journal of Ethnopharmacology, vol. 91, no. 23, pp. 189-208, 2004.

[43] E. A. Carlini, "Plants and the central nervous system," Pharmacology, Biochemistry and Behavior, vol. 75, no. 3, pp. 501-512, 2003.

[44] B. Ahmed, T. Alam, M. Varshney, and S. A. Khan, "Hepatoprotective activity of two plants belonging to the Apiaceae and the Euphorbiaceae family," Journal of Ethnopharmacology, vol. 79, no. 3, pp. 313-316, 2002.

[45] V. De Feo, "Ethnomedical field study in northern Peruvian Andes with particular reference to divination practices," Journal of Ethnopharmacology, vol. 85, no. 2-3, pp. 243-256, 2003.

[46] S. Andrade, S. Arguello, P. Cazamajor et al., Nuevas Investigaciones Antropologicas Ecuatorianas, Editorial Abya Yala, Quito, Ecuador, 1988. 

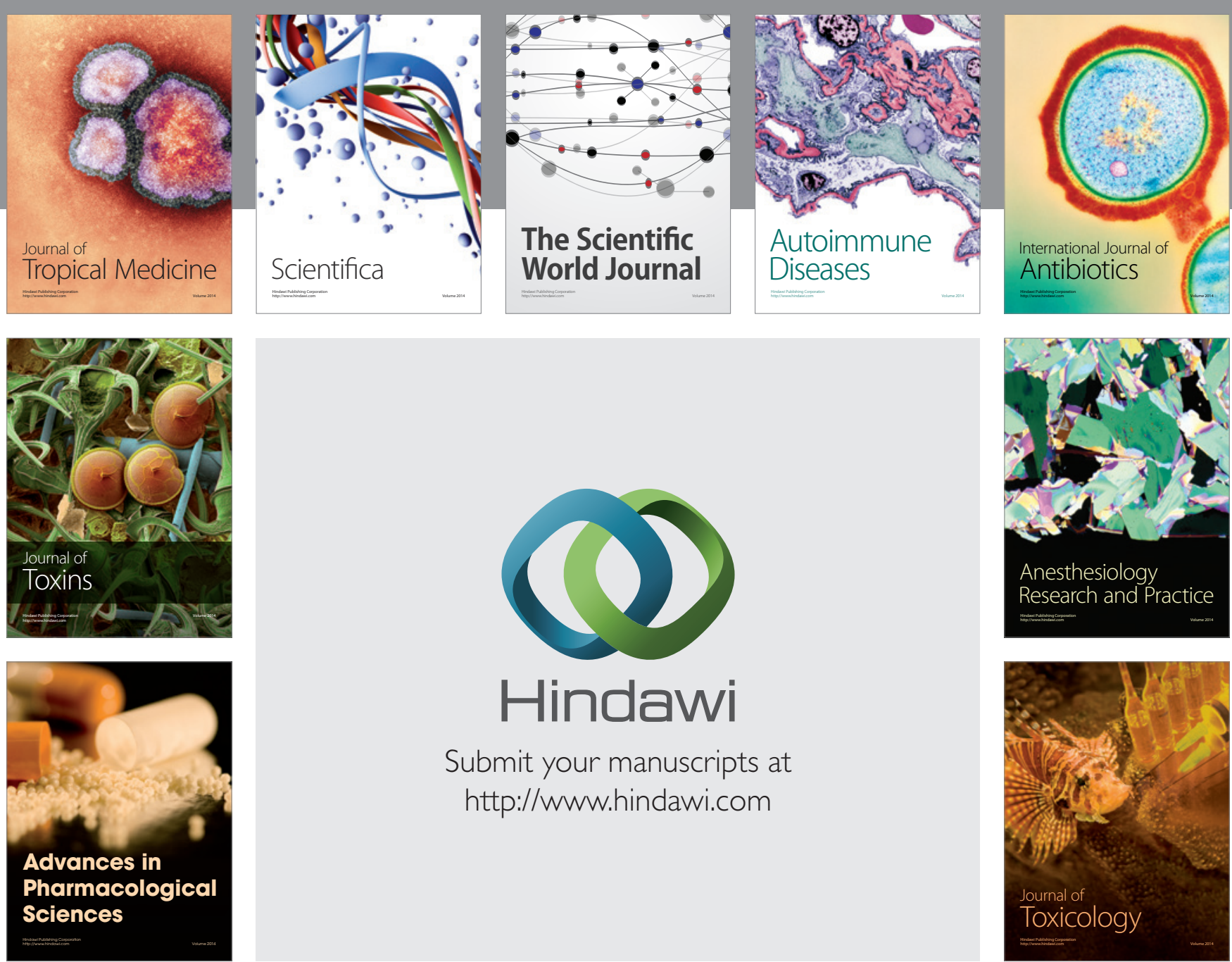

\section{Hindawi}

Submit your manuscripts at

http://www.hindawi.com
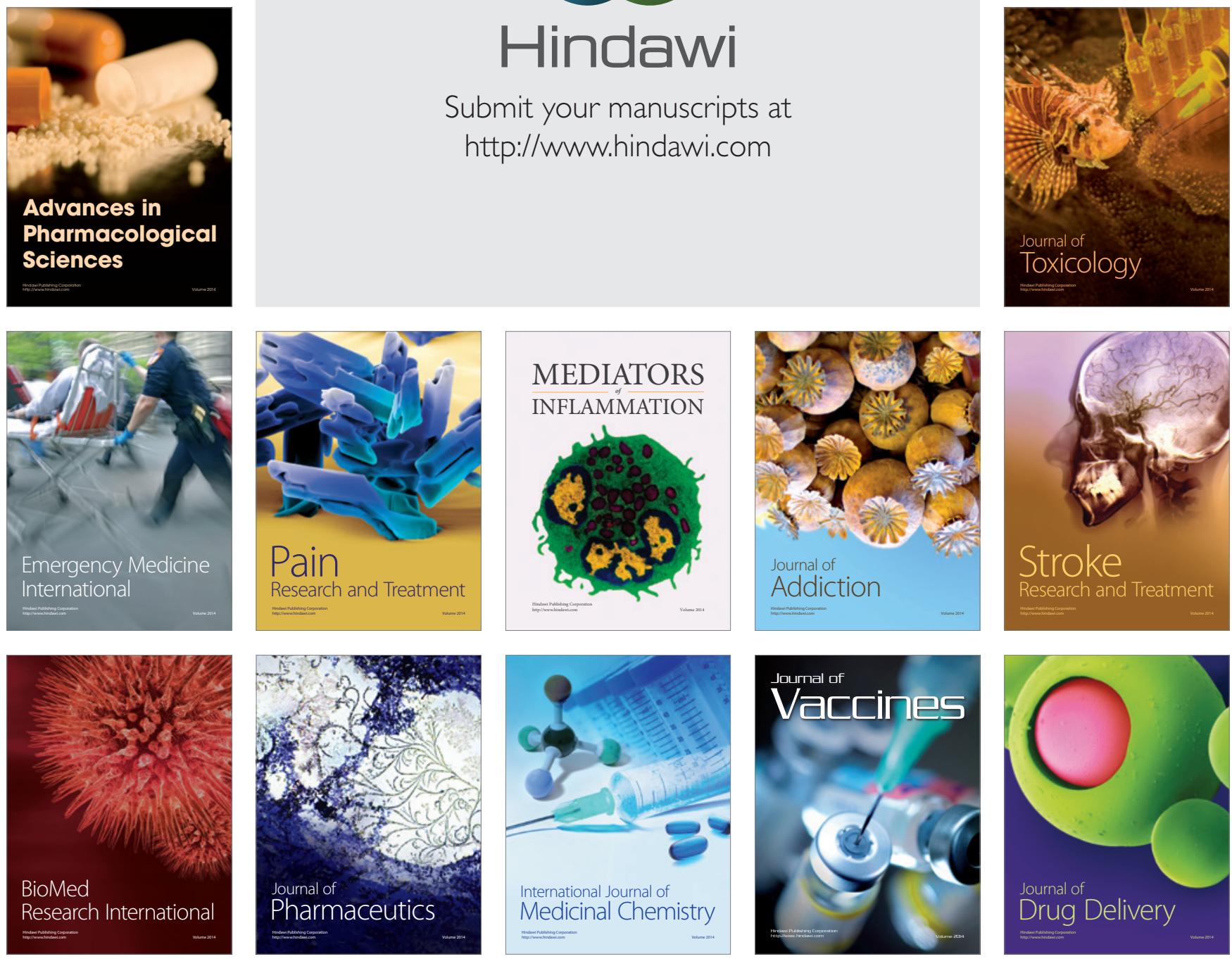